\title{
Taze marul dezenfeksiyonunda ozonlanmıș su kullanımı
}

\author{
Elif SAVAŞ* \\ Balıkesir Üniversitesi, Mühendislik Fakültesi, Gıda Mühendisliği Bölümü \\ Gelis Tarihi (Received Date): 05.09.2019 \\ Kabul Tarihi (Accepted Date): 07.04.2020
}

$\ddot{\mathbf{O} z}$

Taze marul (Lactuca sativa L.) yapraklarının paketleme öncesi kalite parametreleri, taşıdı̆̆ı mikrobial yüke bağll olarak değişmektedir. Bu çalışmanın amacı, taze marul yapraklarının yıkanmasında ozonlanmış su kullanımının bakterisit etkisini belirlemektir. Bu amaçla marul yaprakları ozon jeneratörü ile entegre edilmiş bir ünitede yıkanmıştır. Ylkanan marul yapraklarında toplam bakteri, fekal koliform, E.coli, Staphylococcus aureus, Vibrio spp. sayllarl izlenmiştir. $+4^{\circ} C$ 'de 13 gün depolanan marul örneklerinde analizler doğrudan ya da en uygun tarihten hemen önce analiz edilmiştir. Uygulamada kullanılan su örneklerinde pH ölçümleri yapılmıştır. Depolama sürecinin ilk kısmında toplam kabul edilebilir özelliklerde belirgin bir farklılık gözlenmez iken ilerleyen günlerde belirgin kayıplar meydana gelmiştir. Yıkama işlemi ile toplam mikroflora etkin bir şekilde azalmıştır.

Anahtar kelimeler: Ozon, iceberg marul, E. coli, Staphylacoccus aureus, Vibrio spp..

\section{The usage of ozonated water in fresh-cut lettuce disinfection}

\begin{abstract}
The quality parameters of the pre-packaged iceberg lettuce are affected by microbial invasions. Aim of this study to determination of disinfection effect of ozonated water in the washing process of iceberg lettuce leaves. For this purpose lettuce samples were washed in the commercial foundation integrated with an ozone generator. And than monitored for total bacteria, fecal coliform, E.coli, Staphylococcus aureus, Vibrio spp. counts. The analyses were performed after washing in which lettuces were stored at $4{ }^{\circ} \mathrm{C}$ for 13 days. The sensory evolution was monitored. Water samples were analysed for $\mathrm{pH}$. In the first part of the storage process, no significant changes in acceptable properties were observed. However, a significant decrease was detected in the
\end{abstract}

\footnotetext{
*Elif SAVAŞ, esavas@balikesir.edu.tr, https://orcid.org/0000-0002-4878-0013
} 
population of microorganisms. Negative changes in sensory properties were detected in the second half of the storage process.

Keywords: Ozone, iceberg lettuce, E.coli, Staphylacoccus aureus, Vibrio spp..

\section{Introduction}

Increased demand for healthy nutrition, it also brings the problems of storing these nutrients in natural and fresh conditions. Fresh vegetables and fruits can provide the expected benefits in a storage environment where they can maintain the microbiological and nutritional properties carried under harvest conditions. Especially vegetables cause many epidemics and diseases due to the microorganisms contaminated from the soil and water from which they are harvested. It is known that many food pathogen cases reported with fresh fruits and vegetables can be resolved using effective and practical sanitation and disinfection methods. Ensuring food safety depends on the use of effective sanitation and disinfection methods [1-3]. It is targeted that food pathogens can be completely eliminated or their development stopped completely. The fact that the washing water used in conventional washing processes of fruits and vegetables does not contain residual disinfectant also requires a separate sensitivity.

In addition to the microorganisms in the raw material, usage of dirty washing water, processing and transport equipments as sources of cross contamination, and improper storage are cause of deterioration in fruit and vegetables. Use of appropriate sanitation tools and methods can prevent the deterioration of fruit and vegetable quality due to these possible reasons. Domains of known sanitation means (chlorine, hydrogen peroxide, acidifiers, etc.) can be restricted. The effectiveness of known sanitation means is limited due to some properties such as being inactive against spore forms of microorganisms and being effective at high $\mathrm{pH}$. On the other hand, the fact that residues and cause some chronic diseases (asthma, cancer, etc.) are among the other negative effects. The ease of application and protection without damaging the sensory properties of the product are among the features expected from sanitation materials. Chlorine is one of the most well-known sanitizers. It has many features mentioned above; is an important point in widespread use. Some toxic contaminants as much as food safety also known as a chemical contamination agent pose a risk to food safety. These substances, which are produced as disintegration or conversion products of disinfectants used, can cause harm to human health. Trihalomethanes [4-9], also known as chlorine conversion products, are also included in this group [10-12]. Disinfectant residues or conversion products should not pose a health risk [13].

In recent years, ozone as sanitation agent alternative to chlorine has been used in many food production [11-15]. Ozone, which is effective against bacteria, viruses, yeast, mold and protozoa in a wide spectrum is a sanitation tool that has been approved by the U.S. Food and Drug Administration [15-36]. The profits of ozone treatments $\left(\mathrm{O}_{3}\right)$ was discovered firstly by German chemist Christian Fredrick Schönbein on Switzerland in 1840. The ozone that was used for herbs's water clarification between 1903-1906 years

on the USA, was began to use for clarification of drinking water in 1940's [9]. The ozone applications increased as well as the technologic improvements, easy and low costly ozone production on 1980's [8]. 
Ozone was considered GRAS (generally recognized as safe) status in 1997 provided that it was used within the scope of good manufacturing practices $[9,14,19]$. Although ozone was used for food processing and water clarifications in Europe [14, 20], FDA gave permission to ozone applications on American Food Industry in 2001 [8,21,29]. Ozone has been used to applicated for the food industry as a disinfectant or sanitizer in the US and Europe [9, 31]. But necessary any technical regulations have not been established in Turkey.

Ozone applications reported good results in disinfection of drinking water in food industry and broiler farms. Ozone applications also gave promising results in the decomposition of chemical impurities such as mycotoxins and pesticides in addition to the results related to the reduction of microbial load. Ozone can be used safely in food industry with its properties such as not forming dangerous decomposition products and conversion to oxygen in the application medium. However, ozone usage may cause losses of sensorial properties caused by oxygen damage $(9,18,26)$. It is possible to prevent adverse effects of ozone usage by optimizing product-specific conditions of use. Many sanitation agents are used to ensure the food safety of fresh cut fruits and vegetables and their products. Some have been tested in industrial applications and others have been tested on a laboratory scale. In laboratory experiments, artificial and controlled contaminated food raw material is immersed in aqueous sanitation solution to determine the protective effect. The several factors such as concentration of sanitation agent and duration of antimicrobial action are determined by trials. The results of such studies vary with vaccination method, selection of test organism, vaccination and application time, ambient conditions and recovery of test organism [37,38]. However, in our study, especially in terms of the industry is based on the application of ozone on the natural microflora was investigated.

The aim of this study was to determine the antimicrobial efficacy of ozonated water generated by a recirculating ozone reactor (CFG 20) against various bacteria as pathogens and indicators of fecal contamination on the lettuce. The studies that investigate the disinfection effects of ozone under controlled conditions, is missing an important point which can not be observed physical changes in the product. For that reason we planned our study considering the conditions of production at the plant.

\section{Material and methods}

\subsection{Material}

Iceberg lettuce (Lactuca sativa L.) were harvested in Balikesir (Turkey) province. Lettuce samples were transported to the laboratory $(20 \mathrm{~km})$ under cooling conditions $( \pm$ $4{ }^{\circ} \mathrm{C}$ and $70 \%$ relative humidity (RH)) and processed without waiting. After removing of wrapper leaves heads were cutted. $2 \mathrm{~kg}$ of lettuce samples divided into the five bathches for homogeneous sampling. Lettuce leaves were washed with adapted conditions at $20^{\circ} \mathrm{C}$ under sanitary conditions. Trials were conducted in 3 repetitions. Also similar results were obtained each trials.

\subsection{Technical equipment}

After the outer leaves were removed using knife, the lettuces were indivdually divided into the washing equipment (custom-made bagy) by two-step process: volume washer $1: 2 \mathrm{~m}^{2}$, volume washer $2: 2 \mathrm{~m}^{2}$, custom production pvc cap. After air was compressed 
using a Max Extra Air Liquide compressor, passed discharge $\mathrm{dO}_{3}$ generator (Model CFG 20) to obtain ozone (Figure 1). Gaseous ozone (3 g h-1) by flow $0.12 \mathrm{~nm}^{3} \mathrm{~h}^{-1}$ dissolved in a $50 \mathrm{~L}$ tank by reverse mixer. A thermal destroyer was used as a neutralizer (model DOT 1.1, Ozoneo Electronica Iberica) at $550{ }^{\circ} \mathrm{C}$. Ozonated water was directed by a pump (flow rate of $1 \mathrm{~m}^{3} \mathrm{~h}^{-1}$ ) carry through a stainless steel plate heat exchanger (model UFX 6-11, Barriquand, Roanne Cedex, France). The capacity of joined with a watercooling apparatus was $1.98 \mathrm{~kW}$ (model TAE 015 PO, MTA Srl, Conselve, Italy).In that system ozonated water was recirculated in the washing tank $(50 \mathrm{~L})$ by a circulation pump. The circuit is completed by the second pump which presses water back into the solution tank. In order to measure the amounts of ozone mixed and dissolved in water during the process; an amperometric probe and temperature sompensation sensor were equipped the system (B\&C electronics Srl, Carnate, Milano, Italy). Ozone concentration was measured in two ranges between $0-2$ and $0-20 \mathrm{mg} \mathrm{L}^{-1}$. Instant ozone measurement was also monitored spectrophotometrically for control purposes. Unstable ozone is rapidly decomposed into oxygen by organic compounds, residual chemicals and other factors in the washing water. The most important point is to be able to accurately and instantly measure the ozone concentration in the application tank as a sanitizer. Therefore, inactivation or destruction of microorganisms is associated with disinfectant concentration $\left(\mathrm{C}, \mathrm{mg} \mathrm{L}^{-1}\right)$ and contact time $[\mathrm{t}, \mathrm{min}]$. The product of these two parameters is called the $\mathrm{CT}$ value or dose and expressed in units of $\mathrm{mg} \mathrm{L}^{-1} \min [39]$.

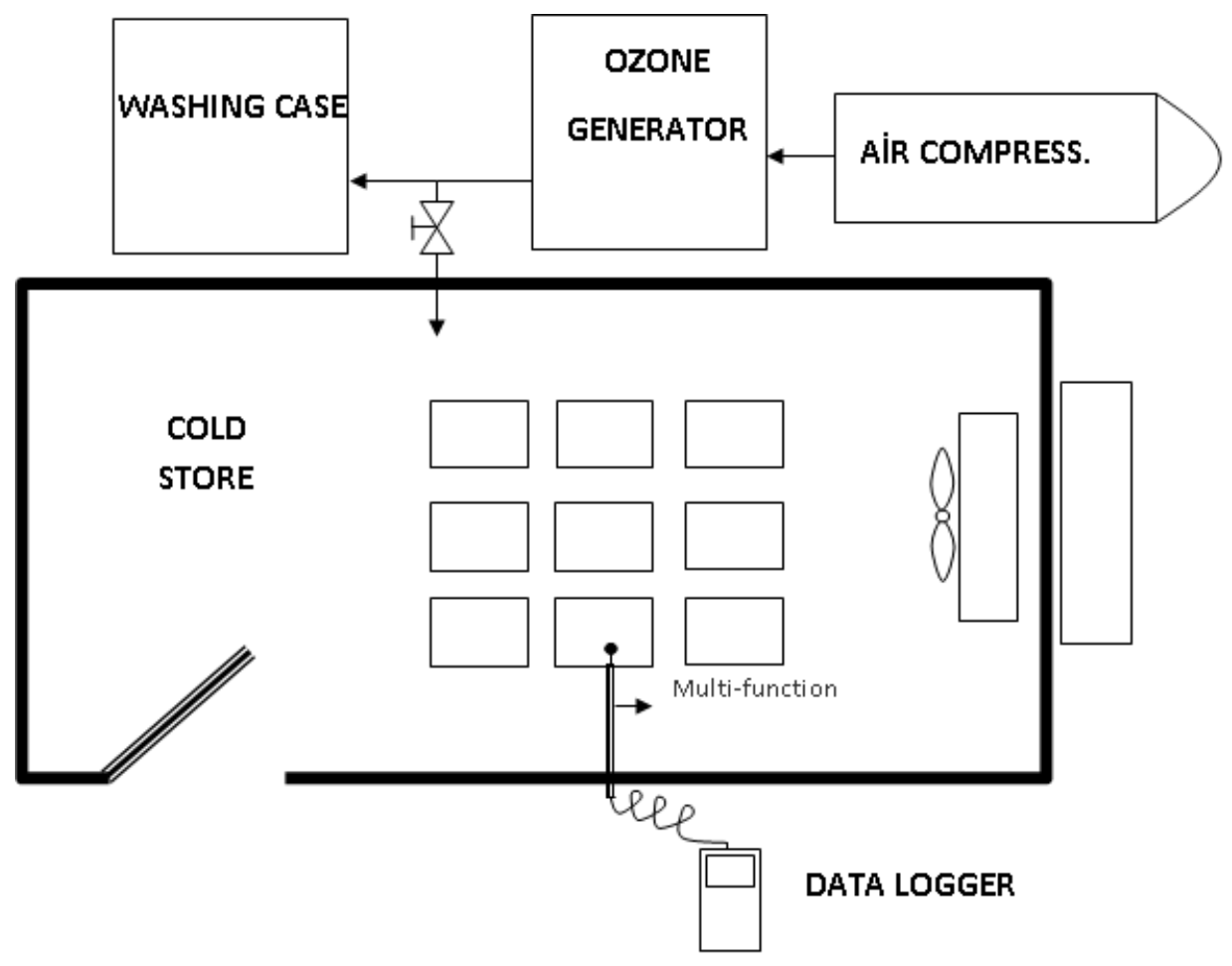

Figure 1. Ozone experiment equipment.

\subsection{Ozone treatment and measurement}

The tap water with chlorine content $100 \mathrm{ppm}\left(\mathrm{mg} \mathrm{L}^{-1}\right)$ was used in the washing process of lettuce samples. It is considered advantageous that the water is filtered and contains chlorine. Ozonation was achieved by generator (CFG 20) as detailed in the technical equipment part. The generator produced $7.2 \mathrm{~g}$ ozone per hour, the flow rate was constant $\left[2 \mathrm{~m}^{3} \mathrm{~h}^{-1}\right]$ during the study. A final ozone concentration was $3.6 \mathrm{ppm}$. 
Lettuces were washed at $20^{\circ} \mathrm{C}$ with two different solutions: (A) The tap water was used as a control sample containing $100 \mathrm{ppm}$ of chlorine. ( $\mathrm{pH} 7.3$ ), (B) $3.6 \mathrm{mg} \mathrm{L}^{-1}$ min total ozone dose. The washing time were respectively $2,4,6,8,10 \mathrm{~min}$ for ozonated water except for tap water, for which the time for treatment was the time that was sufficient to achieve the reported doses (always shorter than $5 \mathrm{~min}$ ) (Figure 2) [40]. The $\mathrm{pH}$ levels were $7.35,7.42,7.57,7.55,7.47$ in $2,4,6,8,10$ min ozonated water. In our study, unwashed lettuce samples were not analyzed where the effect of washing processes was investigated as recommended in other studies $[36,41]$.

\subsection{Packaging}

Lettuce samples were packaged in polypropylene bags (165- 120- $57 \mathrm{~mm}$ ) using with a vacuum packaging machine (Novac, Sakarya, Turkey). All samples were stored for up to 13 days at $4{ }^{\circ} \mathrm{C}$ and evaluated on day 0 and after 5, 9, and 13 days. Three replicates of $100 \mathrm{~g}$ of fresh-cut lettuce were used for each treatment and sampling date.

\subsection{Microbial analysis}

In order to be a realistic industrial assay, the trials were carried out with environmental microflora. The mesophilic bacteria and coliforms in fresh-cut lettuce were monitored a $25 \mathrm{~g}$ sample of fresh-cut lettuce was homogenized with a 1:10 dilution of sterile $1 \%$ peptone-buffered water (AES Laboratoire, Combourg, France) in sterile 400 Lab Stomacher bags (Seeward Medical, London, U.K.) by using a Stomacher (IUL Instrument, Barcelona, Spain] for 90 s.Total aerobic mesophilic bacteria were enumerated by the standard plate count method using plate count agar [PCA Merck] at $30\left(1{ }^{\circ} \mathrm{C}\right.$ for $48 \mathrm{~h}$. Coliforms were isolated using Mac Conkey Broth (Merck) at 37 ( \pm $0.5^{\circ} \mathrm{C}$ for $48 \mathrm{~h}$ ) (according to the MPN method). E.coli were generated by Eocin Methylen Blue Agar (Merck) incubated at $37^{\circ} \mathrm{C}$ during 24 h [37]. S. aureus cells were counted on Baird-Parker Agar (BPA, Merck) incubated at $37^{\circ} \mathrm{C}$ during $48 \mathrm{~h}$ [32]. Vibrio spp. cells were generated on Violet Red Bile Agar (Merck) incubated at $37^{\circ} \mathrm{C}$ during $48 \mathrm{~h}$ [32]. Microbial analyses were achieved on day 0 and after 5, 9, and 13 days of storage. All samples were analyzed in duplicate, and each microbial count is the mean of three samples from three packages. Microbial counts were expressed as log $\mathrm{CFU} \mathrm{g}^{-1}$ of tissue.

\subsection{Sensory evaluation}

The sensorial properties of lettuce samples on $0,5,9$ and 13th days of storage were monitored according to the total acceptability, browning, texture, and aroma by a four membered expert panel. Tthe appearance features of gloss, freshness, and color uniformity and intensity was scored on a 9-1 scale, where 9) excellent, 5) acceptable (limit of marketability), and 1) poor, inedible for evaluating of visual quality. Browning were evaluated as leaf edge and surface on a 5-1 scale, where 5) severe, 3) moderate, and 1) no browning. The texture was marked as 5) very firm and turgid, 3) moderately firm, and 1) very soft. Aroma evaluation points were 5) full typical aroma or flavor, 3) moderate, and 1) none [39].

\subsection{Statistical analysis}

There were three repetitions per treatment and evaluation period. All data represent the mean of three replicates. Analysis of variance (ANOVA) followed by Duncan's multiple range test with a significance level of $\mathrm{p} \leq 0.05$ was performed using SPSS (Windows 2000, Statistical Analysis). 


\section{Results}

The initial load of the total aerobic mesophilic microorganisms in control group was $5.3 \times 10^{4} \mathrm{CFU} \mathrm{g}^{-1}$ and proliferated approximately $50 \%$ to $1.2 \times 10^{5} \mathrm{CFU} \mathrm{g}^{-1}$ within $2 \mathrm{~h}$ of production. The antimicrobial effects of ozonated water and tap water consisting 100 mg. $\mathrm{L}^{-1}$ of chlorine were determined in washed lettuce samples. Trials were achieved at room temperature $\left(19\right.$ to $\left.21^{\circ} \mathrm{C}\right)$. Determined bactericidal activity [log $\left.10 \mathrm{CFU} / \mathrm{ml}\right]$ of ozonated water on lettuce leaves indicated that Table 1. The live cells of E.coli and other microorganisms were decreased by washing with ozonated water for $10 \mathrm{~min}$ (1-3 $\log _{10} \mathrm{CFU} / \mathrm{mL}$ ). The antimicrobial effects of ozone against total viable cells are shown in Figure 2. When antimicrobial effects of ozone application and chlorine-containing tap water usage in lettuce samples were compared; there was no significant difference $(p \leq 0.005)$.

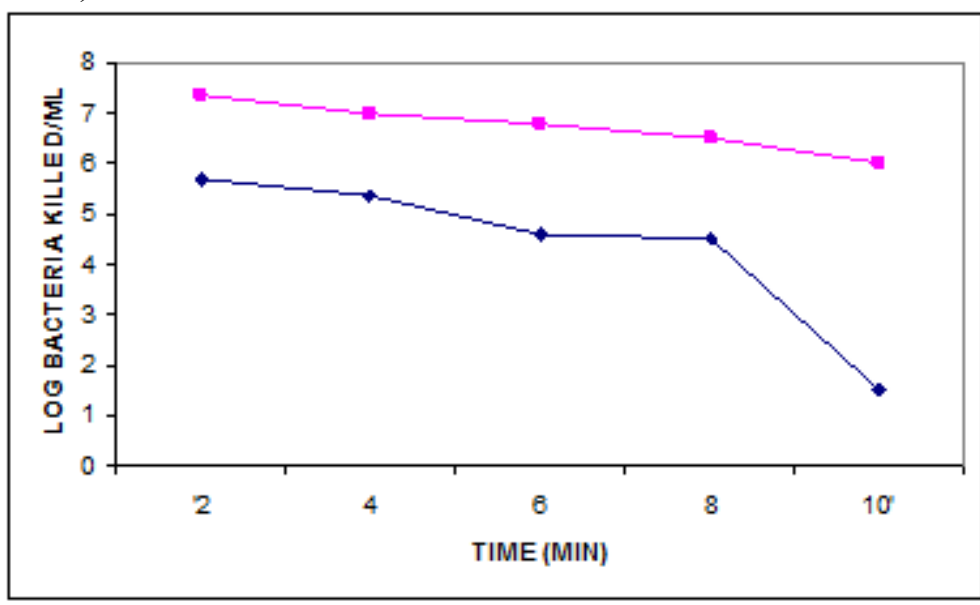

Figure 2. Killing of viable cells of total bacteria by ozone in deionized water. Killing of viable cells of total bacteria by ozone in deionized water with chlorine.

It was determined that the initial antimicrobial effect of gave better results of the washing with ozonated water than only in tap water washing with chlorine. 1 log unit of live cell death per $1 \mathrm{~mL}$ occurred in both sample groups on average.

The death rate curves of ozonated and tap water for fecal coliform are shown in Figure 3. A bit difference was observed in terms of gram negative bacteria. More than $2 \log$ units each of Staphylacoccus spp. and E. coli cells per ml was killed instantaneously [time zero) after exposure to ozonated water (Figure3, 4, 5). There is no significant difference ( $>00.05)$ between ozone treatments at 4, 6, 8, 10 min effects on E.coli and Staphylacoccus spp. death rate. 


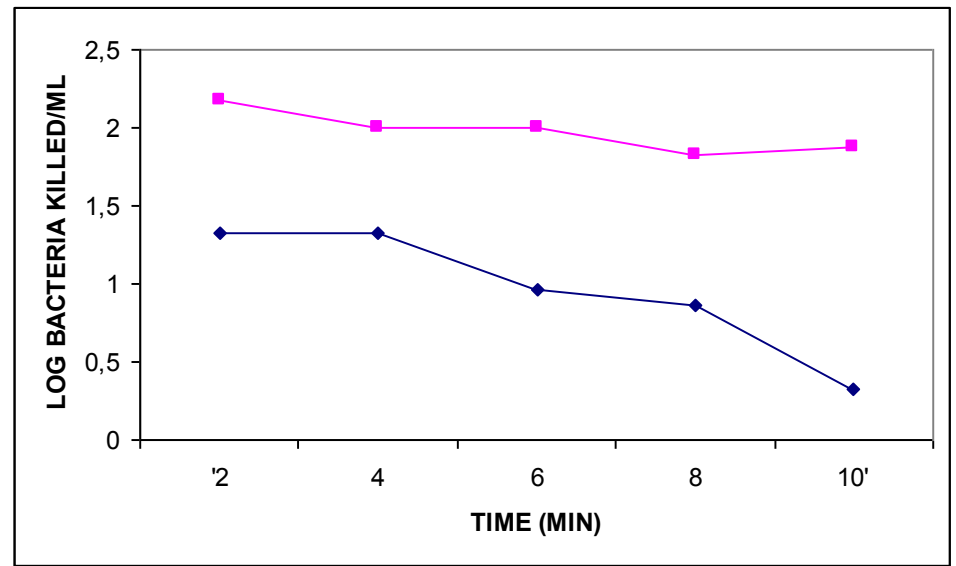

Figure 3. Killing of viable cells of fecal coliform by ozone in deionized water. Killing of viable cells of fecal coliform by ozone in deionized water with chlorine.

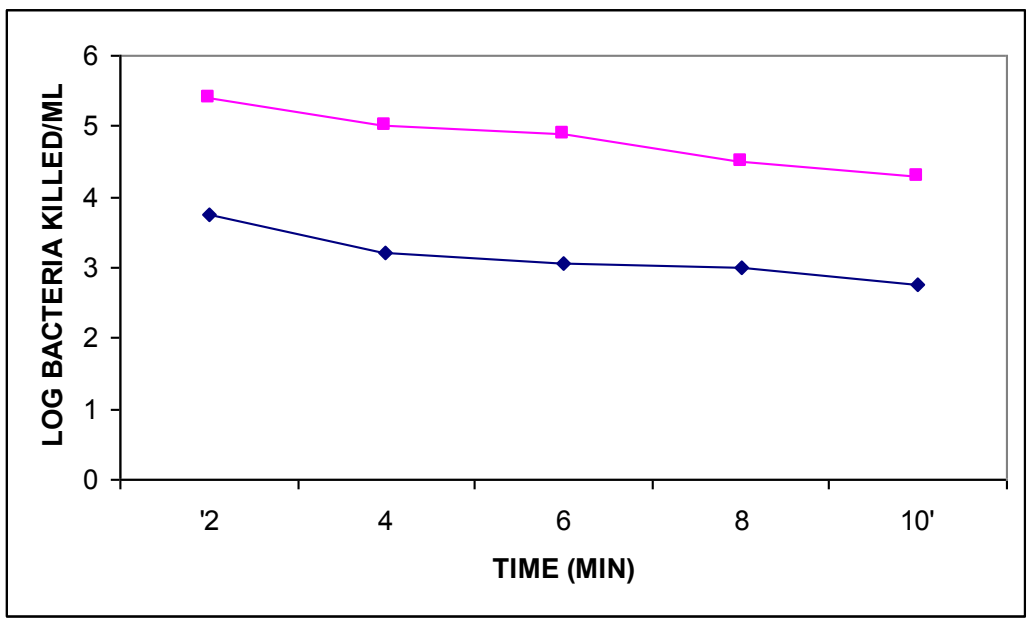

Figure 4. Killing of viable cells of E. coli by ozone in deionized water. $\mathbf{\text { Killing of }}$ viable cells of E.coli by ozone in deionized water with chlorine.

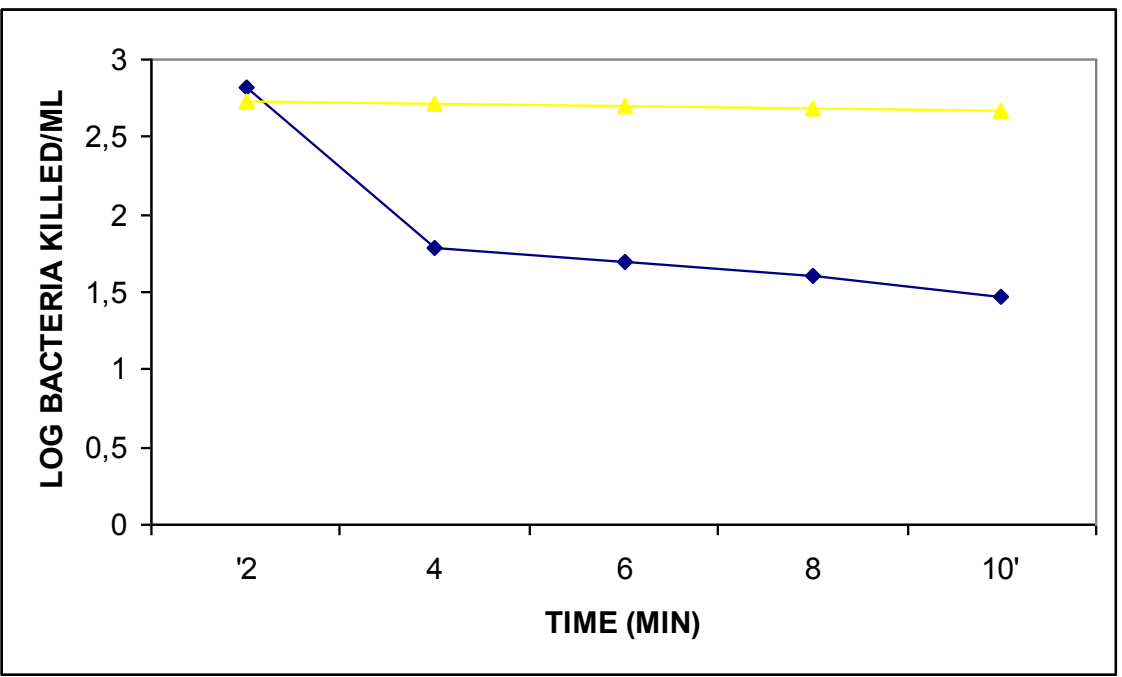

Figure 5. Killing of viable cells of Staphylacoccus spp. by ozone in deionized water. $\Delta$ Killing of viable cells of Staphylacoccus spp. by ozone in deionized water with chlorine. 
Table 1. Bactericidal activity of Ozonated water during washing of lettuce leaves as measured by a different time.

\begin{tabular}{|c|c|c|c|c|}
\hline \multirow{2}{*}{$\begin{array}{l}\text { Water } \\
\text { dip solutions }\end{array}$} & \multicolumn{4}{|c|}{ Surviving population (log10 CFU/mL) on the lettuce leaves } \\
\hline & $\begin{array}{c}\text { Total viable } \\
\text { cells }\end{array}$ & Fecal Coliform & E.coli & Staphylaccoccus spp. \\
\hline $\mathrm{UW}^{*}$ & $3,8.10^{10}$ & $2,7.10^{\prime}$ & $0,9.10^{6}$ & $0,4.10^{3}$ \\
\hline$T^{\star \star}$ & $0,1.10^{8}$ & $1,1.10^{3}$ & $0,18.10^{3}$ & $5,3.10^{2}$ \\
\hline$O W^{\star \star \star} 2 \mathrm{~min}$ & $4,7.10^{5}$ & $2,1.10^{2}$ & $0,8.10^{2}$ & $6,5.10^{2}$ \\
\hline $\mathrm{OW}^{* \star *} 4 \mathrm{~min}$ & $1,8.10^{5}$ & $2,1.10^{2}$ & $0,6.10^{2}$ & $0,6.10^{2}$ \\
\hline$O W^{\star \star \star} 6 \mathrm{~min}$ & $1,31.10^{5}$ & $0,092 \cdot 10^{2}$ & $0,3.10^{2}$ & $0,5.10^{2}$ \\
\hline $\mathrm{OW}^{\star \star \star} 8 \mathrm{~min}$ & $3,9.10^{4}$ & $0,072 \cdot 10^{2}$ & $0,2.10^{2}$ & $0,4.10^{2}$ \\
\hline $\mathrm{OW}^{* \star \star} 10 \mathrm{~min}$ & $0,9.10^{4}$ & $2,1.10^{\circ}$ & $0,1.10^{2}$ & $0,3.10^{2}$ \\
\hline
\end{tabular}

After all washing processes, no color loss such as darkening, fading, yellowing was observed in lettuce samples. The visual quality was found to maintain total acceptable values (Figure 6). But unfortunately, initially obtained promising values were unprotected during storage and significant decrease in visual quality was observed at the end of the day 5 th.

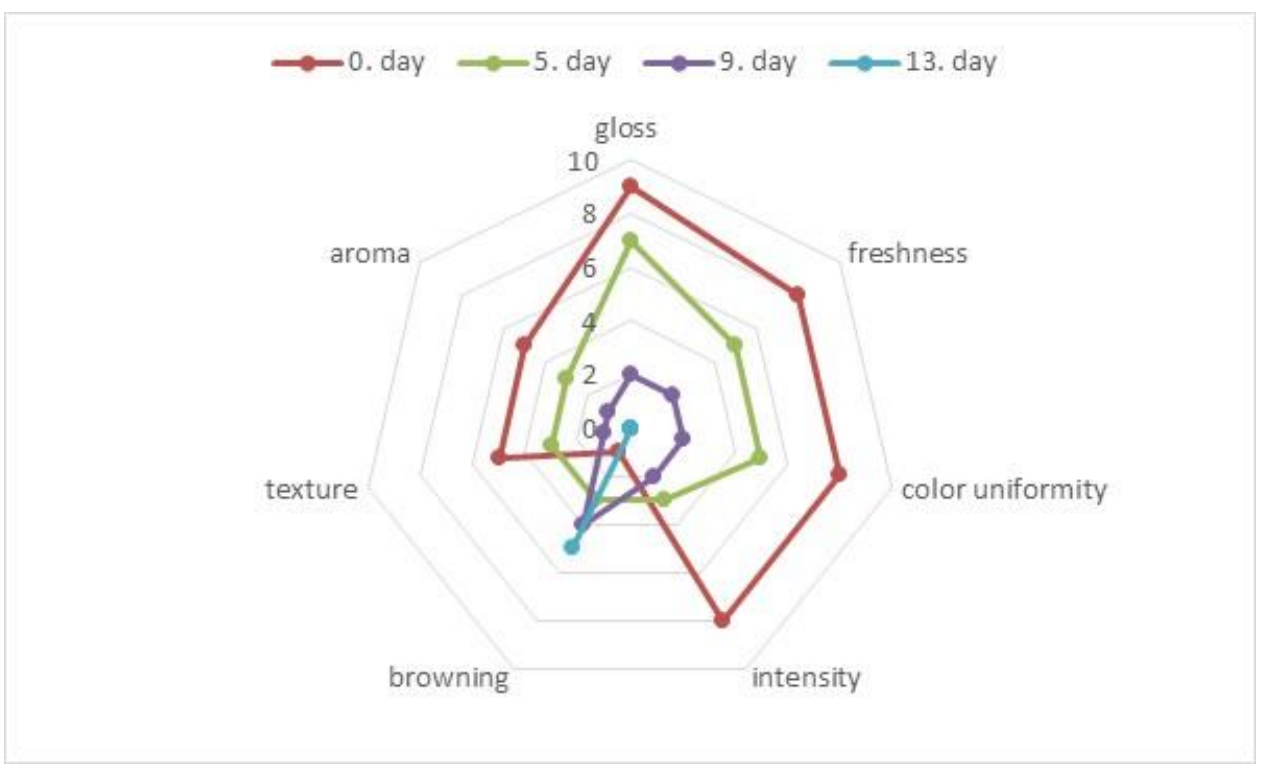

Figure 6. General sensory and visual quality of lettuce samples washed in ozonated water.

After different washing procedures, tissue losses gradually increased during storage. There are no significant variation between applications. The crispy tissue was observed in all samples by day 13 .

\section{Discussion}

Previous studies have declared that chlorine, ozone and chlorine-ozone pairs cause a decrease of $1.1-2.5 \mathrm{log}$ units in aerobic place counts and shelf life of commercial lettuce salads 16, 20 and 25 days. shelf life of commercial lettuce salads increased 16, 20 and 25 days, respectively [27, 28]. On the other hand, no successful results were obtained in pear decay [32] and lettuce leaves inoculated with Pseudomonas fluorescens $[42,43]$. 
The purposes of the washing treatment on the commercial lettuce products are removing soil and other remains, reducing microbial load, limiting the reconstruction of browning and lowering product temperature. After broke and washing with chlorinated water steps (50-200 mg / L free chlorine) leaves were rinsed tap water. However, under the operating conditions in industrial application, the use of ozonated water is becoming widespread. In order to limit the use of chlorine and to reduce microbial load in the washing of cutted lettuce leaves the use of chlorinated and then ozonated water constitutes an alternative washing procedure. In this procedure, many factors, such as the target microorganism, the attachment and interaction of this group of microorganisms to the plant surface, determine the effectiveness of this method used to reduce the charge of the microorganism. Baur et. al. [2004] were declared that washing with ozonated water was more effective on reduction of Enterobacteriaceae species than mesophiles and Pseudomonas [36]. Our results are similar to these researchers. Vibrio was not found on the samples after treatment with ozone [p < 0.05] in $2 \mathrm{~min}$. The reduction in living viable cells of E.coli $\mathrm{O} 157: \mathrm{H} 7$ and L. monocytogenes were decreased on lettuce leaves over than $2.49 \log$ units was reported by Park et al. (2001) [37]. In general, most bacteria, except where sudden death occurs showed effective two-phase death curves when effective ozone levels were reduced in the presence of chlorine (Figure 3). Although washing treatment by ozonated water with $\mathrm{ClO}_{2}$ and thyme oil showed slight effect on microorganisms whereas drop-inoculated samples [27]. The effectiveness of sanitizing agents depend on the method of inoculation, lettuce incubation time, population size and multiple washing treatment [45]. The use of neutral electrolyzed water has been reported to cause significant reductions ( $S$. typhimurium, $E$. coli, and L. monocytogenes population up to $2 \log$ units) in surface microflora in lettuce samples and increased wash efficiency with $300 \mathrm{ppm}$ of chlorine were recorded [46]. Guentzel et. al. (2008) has reported that the biocidal activity of near-neutral electrolyzed water (EW) at $25^{\circ} \mathrm{C}$ on cultures of Escherichia coli, Salmonella typhimurium, Staphylococcus aureus, Listeria monocytogenes, and Enterococcus faecalis [48]. In another study, oxidized water $(2 \cdot 5 \pm 0 \cdot 8) \times 10-3 \mathrm{mmol} 1-1 \mathrm{O}-, 0 \cdot 5 \pm 0 \cdot 2 \mathrm{mmol} 1$ $\left.-1 \mathrm{H}_{2} \mathrm{O}_{2}\right)$ treatment $\left(60 \mathrm{~min}\right.$ at $\left.30^{\circ} \mathrm{C}\right)$ under acidic conditions $(\mathrm{pH} 4 \cdot 30 \pm 0 \cdot 20)$ resulted in reduction of surfce E.coli population (more than $3 \log \mathrm{CFU} \mathrm{ml}{ }^{-1}$ ) [1]. Ozonated water usage in lettuce washing process has been suggested as an alternative method [39, 48]. Sanitizers used in many industrial vegetables such as spinach, leek, asparagus and cabbage to reduce soil-borne microorganisms are important for food safety. It has been reported meaningful results about ozonated water usage in washing step of watercress, spinach, coriander, and celery seeds for reduction in population of Listeria monocytogenes NCTC 7973 and Escherichia coli P36 [49].

Ozone, with the advantages of rapid conversion to oxygen and has no residue, can be safely used as a sanitizing agent for washing green leafy vegetables.

Its protective effect against many known microorganisms (bacteria, cysts of protozoa, viruses, and fungal spores) shows that it is more effective than hypochlorite [50]. Identical to previous findings, ozonated water has shown a protective effect against many pathogens on environmental microflora of lettuce leaves [39].

As a conclusion, the comparison was made according to washing in ozonated water process in 5 different time $(2,4,6,8,10 \mathrm{~min})$, sensory results did not show significant differences ([p>0.05). In analogy with the findings of other studies [36] washing in ozonated water did not show the expected effect literally while reducing the number of 
microorganisms. In this case, the effect of ozone is thought to results from research on the environmental microflora. A wide variety of pathogens are present in the natural microflora in the lettuces which brought to the factory from post-harvest to be processed, the efficiency of the washing operation is determined by remove of the microflora. If conditions such as discharged time, the flow quantity, concentration are optimized, ozone can be used as a disinfectant in the cleaning of lettuce actively.

\section{Acknowledgements}

This study was supported by Balikesir University Scientific Research Projects Unit [BAP] with the project coded 2008/02-44.

\section{References}

[1] Sapers, G.M., Efficacy of Washing and Sanitizing Methods for Disinfection of Fresh Fruit and Vegetable Products. Efficacy of Washing and Sanitizing Methods, Food Technology and Biotechnology, 39 (4), 305-311, (2001).

[2] Sengun, İ.Y. and Kendirci, P., Potential of Ozonated Water at Different Temperatures to Improve Safety and Shelf-Life of Fresh Cut Lettuce, Ozone: Science \& Engineering, 40, 3, 216-227, (2018).

[3] Bahreini, M., Jahed, E., Lotfian, F., Mousavi Khaneghah, A., Ghaderifarah, M., The Efficacy of Ozonated Water on Reduction of Four Food Borne Pathogens and Microbial Quality of Lettuce, Journal of Applied Science and Agriculture, 8(7), 1425-1430, (2013).

[4] Ewell, A.W., Ozone and its application in food preservation, International Journal of Refrigeration, 58, 1-4, (1950).

[5] Haraguchi, T., Simidu, U., and Aiso, K. Preserving effect of ozone to fish. Bulletin of the Japanese Society for the Science of Fish, 35, 915-919, (1969).

[6] Rice, R.G., Ozone in United States of America State-of-the-art, Ozone Science \& Engineering, 21(2), 99-118, (1999).

[7] Parish, M.E., Beuchat, L.R., Suslow, T.V., Haris, L.J., Garrett, E.H., Farber, J.N., and Butsa, F.F., Methods to Reduce/ Eliminate Pathogens from Fresh and Fresh-Cut Produce.Comprehensive Reviews in Food Science and Food Safety, 2, 161-173, (2003).

[8] Ekici L., Sagdıc, O., and Kesmen, Z., Gıda Endüstrisinde Alternatif Bir Dezenfektan: Ozone, GTED, 1, 47-57, (2006).

[9] Karaca H. and Velioglu Y.S. Ozone applications in Fruit and Vegetable Processing, Food Reviews International, 23, 91-106, (2007).

[10] Kaess, G., and Weidemann, J.F., Ozone treatment of chilled beef. I. Effect of low concentrations of ozone on microbial spoilage and surface colour of beef, Journal of Food Science and Technology, 3, 325-334, (1968).

[11] Hassenberg, K., Idler, C., Molloy, E., Geyer, M., Plöchl, M., and Barnes, J., Use of ozone in a lettuce washing process: an industrial trial, Journal of the Science of Food and Agriculture, 87, 914-919 (2007).

[12] Hidaka, T., T. Kirigaya, M. Kamijo, T. Kawamura, and S. Kawauchi., Disappearance of residual chlorine and formation of chloroform in vegetables treated with sodium hypochlorite, Journal of the Food Hygienic Society of Japan, 33, 267-273, (1992). 
[13] Galgano, F., Caruso, M.C., Condelli, N., Stassano, S., and Favati, F., Application of ozone in fresh-cut iceberg lettuce refrigeration, Advances in Horticultural Science, 29(2-3), 61-64, (2015).

[14] Graham D.M., Pariza M., Glaze W.H., Newell G.W., Erdman J.W. and Borzelleca J.F., Use of ozone for food processing, Food Technology, 51, 72-76, (1997).

[15] Achen, M., and Yousef, A.E., Efficacy of ozone against Escherichia coli O157:H7 on apples, Journal of Food Science, 66, 1380-1384, (2001).

[16] $\mathrm{Xu}, \mathrm{L} .$, Journal of Food Technology, 53(10), 58-63, (1999).

[17] Smilanick, J.L., Crisosto, C., and Mlikota, F., Postharvest use of ozone on fresh fruit, Perishables Handling Quarterly, 99, 10-14, (1999).

[18] Schomer H.A., and McColloch L.P., Ozone in Relation to Storage of Apples. USDA Circular, 765, 1-23, (1948).

[19] Kraybill, H.F., Origin, classification and distribution of chemicals in drinking water with an assessment of their carcinogenic potential, In water chlorination: enviromental impact and health effects, Ann Arbor Scientific Publishers, Ins. Ann Arbor, Mich., 1, 211-228 (1978).

[20] Sheldon, B.W. and Brown, A.L. Efficacy of ozone as a disinfectant for poultry carcasses and chill water. Journal of Food Science, 51, 305-309, (1986).

[21] Restaino, L., Frampton, E.W., Hemphill, J.B., and Palnikar, P. Efficacy of ozonated water against various food-related microorganisms, Applied and Enviromental Microbiology, 3471-3475, (1995).

[22] Guzel-Seydim Z.B. The Use of Ozonated Water as a Cleaning Agent in Dairy. Thesis. Suleyman Demirel University, 32260 Cunur, Isparta, Turkey, (1996).

[23] Zagory, D., and Hurst, W.C. [Eds.]: Food Safety Guidelines for the Fresh-cut Produce Industry, International Fresh-cut Produce Association, Alexandria, V.A. (1996).

[24] Strasser J. Ozone applications of apple processing, Tech. Application, Electric Power Research Institute, Inc., Palo Alto, CA., (1998).

[25] Anonymous. Secondary Direct Food Additives Permitted in Food for Human Consumption. Rules and Regulations, Ozone, Final Rule, 66, 123, 173-368, (2001).

[26] Koseki S., Yoshida K., Isobe S., and Itoh K. Decontamination of Lettuce Using Acidic Electrolyzed Water, Journal of Food Protection, 64 (5), 652-658, (2001).

[27] Singh N., Singh R.K., Bhunia A.K. and Stroshine R.L. Efficacy of Chlorine Dioxide, Ozone, and Thyme Essential Oil or a Sequential Washing in Killing Escherichia coli $\mathrm{O} 157: \mathrm{H} 7$ on Lettuce and Baby Carrots, Lebensmittel Wissenschaft und Technologie, 35, 720-729, (2002).

[28] Garcia A., Mount J.R., and Davidson P.M. Ozone and Chlorine Treatment of Minimally Processed Lettuce, Journal of Food Science, 68 (9), 2747-2751, (2003).

[29] Palou L., Smilanick J.L., Crisosto C.H., Mansour M., and Plaza P. Ozone Gas Penetration and Control of the Sporulation of Penicillium digitatum and Penicillium italicumwithin Commercial Packages of Oranges during Cold Storage, Crop Protection, 22, 1131-1134, (2003).

[30] Smilanick J. Use of ozone in storage and packing facilities. Washington Tree Fruit Postharvest Conference, December 2nd and 3rd, Wenatchee, WA. (2003). 
[31] Anonymous. FAQs on ozone, Food Revolution, 32 (9), 43-44, (2005).

[32] Halkman A.K. Merck Gida Mikrobiyolojisi Uygulamaları, Ed. Başak Matbaacilık Ltd. Şti., Ankara, 358 s, (2005).

[33] Tan, B.K., Watson, I.A., Patron, R., and Peden, I. A Real-Time Monitoring and Detection Instrument for Analysis of the Effects of O3 on Bioluminescent Escherichia coli on AgarSurfaces-Potential Applications of the Food Industry, Innovative Food Science and Emerging Technologies, 6, 183-188, (2005).

[34] Smilanick J. Photos of Fruits and Vegetables Treated with Ozone. UCDAVIS Postharvest Technology Research \& Information Center, USDA-ARS, Fresno, (2006).

[35] Daş, E., Gürakan, G.C., and Bayındırlı, A. Effect of Controlled Atmosphere Storage, Modified Atmosphere Packaging and Gaseous Ozone Treatment on the Survival of Salmonella enteritidis on Cherry Tomatoes, Food Microbiology, 23 (5), 430-438, (2006).

[36] Baur S., Klaiber R., Hammes, W.P., Carle R. Sensory and microbial quality of shredded, packaged iceberg lettuce as affected by pre-washing procedures with chlorinated and ozonated water, Innovative Food Science and Emerging Technology, 5, 45-55, (2004).

[37] Park, C.M., Hung, Y.C., Doyle, M.P., Ezeike, G.O.I., and Kim, C., Pathogenic reduction and quality of lettuce treated with electrolyzed oxidizing and acidified chlorinated water, Journal Food Science, 66, 1368-1372, (2001).

[38] Izumi, H., Electrolyzed water as a disinfectant for fresh-cut vegetables. Journal of Food Science, 64, 536-539, (1999).

[39] Beltran, D., Selma, M.V., Marian, A. and Gil, M.I. Ozonated Water Extends the Shelf Life of Fresh-Cut Lettuce, Journal of Agricultural and Food Chemistry, 53, 5654-5663, (2005).

[40] Hassenberg, K., Fröhling, A., Geyer, M., Schlüter, O. and Herppich, W.B., Herppich Ozonated Wash Water for Inhibition of Pectobacterium carotovorum on Carrots and the Effect on the Physiological Behaviour of Produce, European Journal of Horticultural Science, 73(1), 37-42, (2008).

[41] Pirovani, M., Piagentini, A., Gemes, D., and Arkwright, S. Reduction of chlorine concentration and microbial load during washingdisinfection of shredded lettuce. International Journal of Food Science and Technology, 39, 341-347, (2004).

[42] Spotts, R.A., and Cervantes, L.A., Effect of Ozonated Water on Postharvest Pathogens of Pear in Laboratory and Packinghouse Tests, Plant Disease, 76, 256-259, (1992).

[43] Kim, J.G., Yousef, A.E., and Chism, G.W., Use of Ozone to Inactivate Microorganisms on Lettuce. Journal of Food Safety, 19, 17-34, (1998).

[44] Kim, J.-G., Yousef, A.E. and Dave, S., Application of ozone for enhancing the microbiological safety and quality of foods: a review. Journal of Food Protection, 62, 1071-1087, (1999).

[45] Yang, H., Swem, B.L. and Li, Y., The effect of $\mathrm{pH}$ on inactivation of pathogenic bacteria on fresh-cut lettuce by dipping treatment with electrolyzed water, Journal of Food Science, 68 (3), 1013-1017, (2003).

[46] Wang, L., Gong, L., Zhao, E., Yu, Z., Torimoto, Y., Sadakata, M., and Li Q.X., Inactivation of Escherichia coli by $\mathrm{O}^{-}$water, Letters in Applied Microbiology, 45(2), 200-205, (2007).

[47] Guentzel, J.L., Lam, K.L., Callan, M.A., Emmons, S.A. and Dunham, V.L., Reduction of bacteria on spinach, lettuce, and surfaces in food service areas 
using neutral electrolyzed oxidizing water, Food Microbiology 25, 1, 36-41, (2008).

[48] Koseki S., and Isobe S., Effect of ozonated water treatment on microbial control and on browning of iceberg lettuce [Lactuca sativa L.]. Journal of Food Protection, 69(1): 154-160, (2006).

[49] Warriner, K.F., Ibrahim, F., Dickinson, M., Wright, C., and Waites, W.M., Seed decontamination as an intervention step for eliminating Escherichia colion salad vegetables and herbs, Journal of the Science of Food and Agriculture, 85(13), 2307-2313, (2005).

[50] Bachelli, M.L.B., Amaral, R.D.A., Benedetti, B.C., Alternative sanitization methods for minimally processed lettuce in comparison to sodium hypochlorite, Brazilian Journal of Microbiology, 44, 3, 673-678, (2013). 